\title{
Some relations between the habitat, behaviour, and metabolism on exposure to air of the high-level intertidal cirripede Chtbamalus depressus (Polli) ${ }^{1}$
}

\author{
Harold Barnes and Margaret Barnes \\ The Marine Station, Millport, Scotland \\ and Station zoologique, Villefranche-sur-Mer, France
}

KURZFASSUNG: Einige Beziehungen zwischen Habitat, Verhalten und Stoffwechsel bei Luftexponierung des den höheren Gezeitenbereich bewohnenden Cirripediers Cbtbamalus depressus (Polli). C. depressus vermag lange außerhalb des Wassers zu leben und stellt somit ein ideales Versuchstier dar für Studien ïber die Wirkungen von Trockenfallperioden. Es wird ein kurzer Abriß der bisherigen Ergebnisse über biochemische Veränderungen während der Luftexponierung gegeben. In Luft erfolgt eine Verringerung der Sauerstoffaufnahme, wobei der Unterschied zwischen $C$. depressus vom unteren und oberen Gezeitenbereich sehr ausgeprägt ist. In den ersten 7 Tagen steigt der Milchsäuregehalt geringfügig. Dieser Umstand deutet auf eine geringe anaerobe Stoffwechselintensität hin. Die quantitativen Veränderungen einiger phosphorilierter Intermediärprodukte werden untersucht. Die auffälligste Veränderung betrift den ATP-Gehalt, welcher in den ersten 3 Tagen auf die Hälfte absinkt. Es tritt ferner eine deutliche Anreicherung von Glukose-6-Phosphat ein. Die Beziehungen zwischen dem Verhalten der Tiere, dem Wasserverlust und den biochemischen Veränderungen werden diskutiert.

\section{INTRODUCTION}

It has been shown that a number of common cirripedes, both intertidal and sublittoral, are able to withstand anaerobic conditions over considerable periods (BARNEs, Finiayson \& Piatigorsky 1963). In isolated, whole, dissected bodies lactic acid in produced in quantity and on return to aerobic conditions it is largely and rapidly excreted, very little being oxidized or re-synthesized to glycogen. A resort to anaerobiosis might have been expected in an intertidal species such as Balanus balanoides or Chthamalus stellatus if, to conserve moisture, they close the mantle cavity on exposure to air. These species, however, survive a normal intertidal period at the levels they most commonly occupy on the shore largely by their adaptive behaviour to the changed conditions; water loss is restricted and access to oxygen maintained via an opercular micropyle which intermittently puts the mantle cavity in communication with the external atmosphere. The survival value of the facultative anaerobiosis may be in the fact that it allows the animals to withstand abnormal conditions - extreme exposure,

1 This work was carried out under O.N.R. contract NR 104-745 and gratitude is expressed to the Office of Naval Research for its support and to the Station zoologique, Villefranchesur-Mer, for facilities. 
high temperature, lowered salinity, and possibly pollution, - when the micropyle may remain closed and the mantle cavity, therefore, unable to renew its oxygen. Under experimentally induced anaerobic conditions or on long exposure to air (when only part of the population may survive) intact animals resort to anaerobic metabolism with the production of lactic acid. Even so, the amount of lactic acid formed falls far short of that expected on the basis of aerobic respiration - as is the case with many animals; there appears to be a suppression of metabolism under these conditions.

C. depressus (PoLli) is remarkable in its capacity to live out of water; it occurs high up the shore in a specialized habitat and much of any population is only rarely immersed. For the most part it depends upon wave action, and many individuals in any given locality only have access to water at infrequent intervals (BARNEs \& Barnes 1964). In a series of investigations Monterosso (see 1932 for references) has shown that $C$. depressus remains viable when kept out of water for many weeks and will withstand immersion in oil for 14 days. He kept animals alive for many months immersing them in sea water for a few hours at infrequent intervals. This species would seem, therefore, ideal for further investigating the metabolism associated with an extreme high intertidal habitat.

\section{MATERIAL AND METHODS}

In order to avoid any changes subsequent to removal from the substratum and prior to analysis, a large number of stones bearing $C$. depressus were broken from the shore and maintained in the laboratory; one group was kept in air and another completely immersed in an aquarium tank with well aerated sea water. C. stellatus when required was readily available on the nearby shore. To get stones in this way is somewhat difficult and the material was of necessity limited. Only animals were used which did not contain egg masses. The resting value of the oxygen uptake was determined on animals carefully dissected from the shell; only a limited number of size groups were available. The method has been fully discussed by Barnes, Barnes \& FinlaySON (1963a). For analysis the animals were removed from the stone and the bodies quickly dissected from the shell, and weighed. They were then homogenized in a Potter-Elvehjem homogenizer with ice cold $10 \%$ trichloroacetic acid. Subsequent fractionation was carried out as quickly as possibly keeping all reagents and preparations cold. A second sample of the animals was taken and the loss on oven drying $\left(105^{\circ} \mathrm{C}\right)$ determined. All results are expressed on an oven dry basis. The methods used for the estimation of glycogen, lactic acid and the phosphorylated intermediates are those given in UMBreIT, BurRis \& STAuffer (1945). Arginine and arginine phosphate were determined as described by ENNOR (in: Methods in Enzymology, ED. Colow ICK \& Kaplan 1957). It is fully realized that the barium fractionation technique for the estimation of phosphorylated intermediates has, except for preliminary separations, been largely replaced by more sophisticated methods. It is, however, quite adequate for a preliminary investigation which is concerned rather with the relation of general metabolism to the ecological niche of an animal than with the detailed enzyme biochemistry of isolated tissues or cells. 


\section{RESULTS}

\section{Respiration}

The relation between the oxygen uptake of whole dissected bodies $(\mu / \mathrm{g}$ dry weight/hr.) and body size (mg dry weight) for C. stellatus and C. depressus is shown in Figure 1. On a log-log scale the relation is linear. The values for $C$. depressus taken low down amongst the $C$. stellatus are, at the same body weight, somewhat lower than those for C. stellatus, indicating that the former has a smaller intrinsic metabolic rate. This is in agreement with the differences in oxygen uptake between other Chtbamalus sp. and their associated lower littoral and sublittoral species; there is a

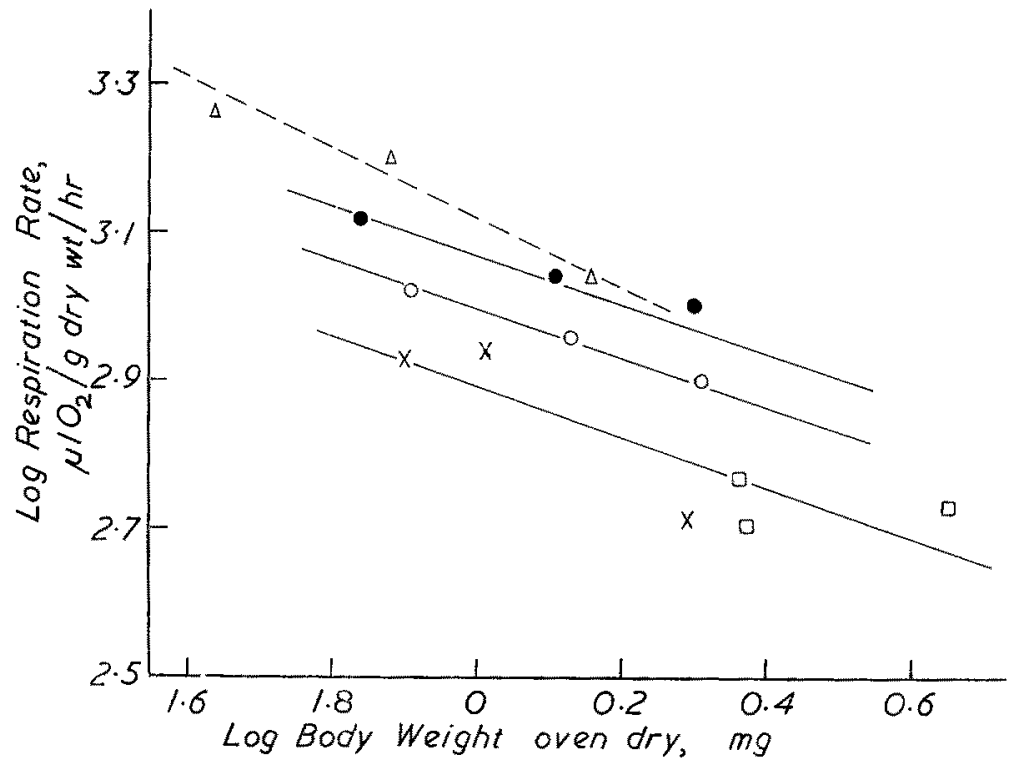

Fig. 1: The relation between oxygen uptake ( $\mu \mathrm{l} / \mathrm{g}$ dry weight/hr.) and body weight (mg dry weight) on a logarithmic basis for $C$. stellatus and $C$. depressus: $\triangle$ C. stellatus freshly collected; $O, C^{-}$. depressus from two low shore levels, freshly collected; $\square$ C. depressus high shore levels, freshly collected; $X C$. depressus after maintaining in air for 14 days

tendency for the higher level genus to have a lower metabolic rate, and this in turn is related to the lower intrinsic growth rate of Chtbamalus sp. even when conditions are optimal (raft exposure) (Barnes 1958, Barnes \& BARnEs 1959). The difference between low level $C$. depressus and $C$. stellatus is small; there is a much more marked difference between $C$. depressus taken from low levels and from the upper shore where they had all the appearance of not having been wetted for some time - or from stones which had been maintained in air in the laboratory for two weeks; the latter animals were quite moist and fully viable. 


\section{Lactic acid}

The lactic acid content of the bodies from fresh animais collected from the extreme upper levels (dry), from extreme lower levels (where they were mixed with C. stellatus; wet), and of the former after standing in air in the laboratory for seven days is shown below:

Lactic acid ( $\mathrm{mg} / \mathrm{g}$ dry tissue)

$\begin{array}{ll}\text { Freshly collected, dry } & 0.68 \\ \text { Freshly collected, wet } & 0.58 \\ \text { In air for seven days } & 0.96\end{array}$

Animals from the extreme upper levels (it is not known how long they had been out of water) had a slightly higher lactic acid content than those at lower levels; the values are similar, although somewhat lower, to the resting values previously quoted for C. stellatus and other species. The increase over a period of 7 days, namely $0.38 \mathrm{mg} / \mathrm{g}$ dry tissue is small. This may mean that there has been little resort to anaerobic metabolism but more probably that the metabolism is at an extremely low level. Balanus balanoides on exposure to air was found to accumulate $1.5 \mathrm{mg} / \mathrm{g}$ lactic acid over a seven day period which was shown to be only $1 / 10$ of the rate of whole dissected bodies under fully anaerobic conditions (Barnes, FinLayson \& Piatigorsky 1963). The intrinsic metabolic rate (and the growth rate) of $C$. depressus is even lower than that of $C$. stellatus; the rate when depressed by continuous exposure to air is extremely low and is an important factor in the ability of the animal to withstand long periods out of water with the accompanying starvation (see p. 26).

Glycogen

The glycogen content of animals remaining completely immersed and of those exposed to air for six days after collection is shown below:

Glycogen, $\mathrm{mg} / \mathrm{g}$ dry tissue

$\begin{array}{ll}\text { Immersed } & 24.2 \\ \text { Dry } & 27.0\end{array}$

The difference is small and probably within the error due to sampling and analysis. What is significant is that after 6 days starvation no depletion of the glycogen could be detected. During starvation it has been shown that, when present, glycogen (and glucose) are first used by cirripedes and the absence of any gross fall in the value after starvation is a further indication of a low metabolic rate. 


\section{Inorganic phosphate, ATP, and phosphoarginine}

The values for these substances in the bodies of the two groups (wet and dry) of animals after three days in either water or air are shown below, together with inorganic phosphate and ATP-P after a further three days.

\begin{tabular}{|c|c|c|c|c|}
\hline & & & Content & $y$ tissue \\
\hline & & Inorganic-P & ATP-P & PA-P \\
\hline $3 d$ & Immersed & 10.0 & 1.5 & 0.5 \\
\hline 5 days & Dry & 13.5 & 0.8 & 2.0 \\
\hline 6 days & Immersed & 12.5 & 1.5 & - \\
\hline & Dry & $9.8(?)$ & 0.76 & - \\
\hline
\end{tabular}

The most striking feature of these results is the fall in the ATP-P to half its normal value during the first three days of exposure to air and the concomitant increase in the PA-P. The fall in ATP is almost certainly causally related to the gross reduction, already noted, in the metabolic rate. During the next three days there is only a further small loss in ATP; whether on long exposure the ATP is reduced further is not known, but the early loss of ATP means that the mechanism ensuring a reduced metabolism is initiated soon after transfer to the 'unfavourable' conditions. The results invite comparison with those of Hescop, Price \& Ray (1963) on the changes in ATP in the housefly (Musca domestica) under conditions of anoxia. They found that when the flies are subjected to an atmosphere of nitrogen, after a short period of hyperactivity, they collapse and remain motionless; on return to air they resume activity. In anoxia there was a rapid fall in the ATP content, which according to RAY \& HesLoP (1963), is broken down to AMP and IMP: at the same time they found a break down of phosphagen and an accumulation of glycerol-1-phosphate. The analogy is far from complete; some activity continues in Cbthamalus depressus on continued exposure to air and there is a change over to anaerobic metabolism with the production of lactic acid. HesLop, PRICE \& RAY (loc. cit.) suggest that in anoxic flies when the normal respiratory chain is blocked, the pathway leading to glycerol-1-phosphate soon ceases to be effective. Any further change is unlikely with reduced ATP values and although there was a slight increase in glycerol there was no movement of the phosphorus between the acid-soluble and phospholipid pools. They therefore regarded glycerol-1-phosphate as an accumulated end-product under anoxic conditions.

The increase in phosphagen stands in marked contrast to the findings of Hestop, PrICE \& RAY. The part played by these substances other than their well known role in a reversible phosphoryl group transfer reactions with the adenylic acid system during muscular activity is obscure (for a discussion see Morrison \& ENNOR 1960). Certainly the old belief that they are restricted to those tissues on which sudden demands for work are made cannot be maintained. The phosphoarginine content of the whole bodies of $C$. depressus is low compared with that of crustacean muscle; this would be expected since although present (around the prosoma and in relation to the appendages) muscular tissue makes up only a small part of the dissected bodies. (The largest muscles in cirripedes are those attached to the valves and these were not in- 
cluded in the material analysed.) On transference to air movements of cirri and body are grossly reduced; some movements take place on first transferring to air and these probably serve to ventilate the mantle cavity and maintain aerobic respiration (BARNes, Finlayson \& Pratigorsky 1963). The accumulation of phosphoarginine may arise from this reduction in muscular activity. In view of the fact that whole bodies were used it is not possible to determine the contribution of the various tissues to these changes; however, ATP is clearly lost at sites where it cannot be regenerated from the phosphagen. In view of the ATP breakdown an increase in true orthophosphate would have been expected; such was found after three days but the increase is greater than that expected on the basis of the change in the ATP-P values. The origin of this phosphate is unknown.

\section{Hexose phosphates}

The values for some hexose phosphates are given below:

\begin{tabular}{c|cccc} 
& & \multicolumn{3}{c}{ Hexose phosphate, $\mathrm{mg} / \mathrm{g}$ dry tissue } \\
& & Fructose-6-P & Fructose di-P & Glucose-6-P \\
\hline \multirow{2}{*}{ days $\quad\left\{\begin{array}{l}\text { Immersed } \\
\text { Dry }\end{array}\right.$} & 0.93 & 0.93 & 2.38 \\
& 1.38 & 1.15 & 10.0
\end{tabular}

There is a marked accumulation of glucose-6-P on drying. It is not known whether glucose or glycogen is the immediate precision of glucose-6-P in the overall metabolism in cirripedes (or other crustaceans). These results suggest that since there is an accumulation of glucose-6-P on drying at the same time that there is a marked fall in the ATP content, glycogen may be the immediate precursor since the conversion via glucose-1-P requires no ATP, involving successively phosphorylase and phosphoglucomatase. The accumulation could then be accounted for as a result of retardation (consequent upon the reduced ATP content) of subsequent transformations requiring $A T P$.

\section{Pentoses}

A single series of analyses were made on the total pentose content of the bariumsoluble alcohol-insoluble fraction; this fraction includes adenylic acid, pentose phosphates, and co-enzymes. On exposure to air for six days the pentose (arabinose standard) rose from 0.44 to $0.75 \mathrm{mg} / \mathrm{g}$ dry weight tissue. Some of the increase may have been the result of the breakdown of ATP (see above) but the values and their difference cannot be nearly accounted for in that way. Although little more than speculation, it may be suggested that the high pentose values result from the intervention of the alternative pathway of carbohydrate metabolism, the hexose monophosphate shunt. This, involving ribulose phosphate, does not require ATP since the fructose- 1 to fructose diphosphate transformation is by-passed. It is tempting to associate the increase in pentose on drying with an increase in this ATP-sparing pathway. 


\section{ATP-ases}

Prof. E. ScHoffentels of the University of Liege kindly made estimations of the ATP-ase content, in the presence of low and high $\mathrm{Na}^{+}$ion concentrations, of immersed and dry C. depressiss after seven days, with the following result.

ATP-ase $\mathrm{P}, \mu \mathrm{M} / \mathrm{g}$ dry tissue

$\begin{array}{llr}\text { Immersed } & \text { (with } 16 \mu \mathrm{E} \mathrm{Na} / \mathrm{ml} \text { ) } & 148 \\ \text { Immersed } & \text { (with } 416 \mu \mathrm{E} \mathrm{Na} / \mathrm{ml} \text { ) } & 143 \\ \text { Dry } & \text { (with } 16 \mu \mathrm{E} \mathrm{Na}^{+} / \mathrm{ml} \text { ) } & 80 \\ \text { Dry } & \text { (with } 416 \mu \mathrm{E} \mathrm{Na}+/ \mathrm{ml} \text { ) } & 92\end{array}$

There is a marked fall in the ATP-ase content on exposure to air which is coincident with the fall in ATP already discussed. In the case of the dry animals he considers the difference between the values at the two $\mathrm{Na}^{+}$ion concentrations may be significant-particularly since only one $\mathrm{Na}^{+}$ion concentration was used which may not have been optimal; if valid, the results indicate the presence of two ATP-ases in the air-exposed animals, one of which is activated by sodium ions: in view of the fact that whole bodies were used and that results are based on a single sample, the findings are not stressed. It is, however, of interest to note that an increased $\mathrm{Na}^{+}$ion concentration would arise in the air-exposed animals because of their loss of water. On the other hand, $416 \mu \mathrm{E} \mathrm{Na}+/ \mathrm{ml}^{2}$ is about the value for normal sea water; we have no data on which to calculate the real effect of the known loss of water on the true sodium. content.

\section{DISCUSSION}

We may now enquire how far this preliminary biochemical investigation has thrown any light on the mechanisms enabling cirripedes (and by analogy possibly other intertidal invertebrates) to withstand exposure to air and in what way species differ from one another. With respect to the contrast between intertidal and sublittoral cirripedes there can be little doubt that the primary differentiation, as already stressed, is in the behaviour on transference to air: the intertidal cirripedes adapt in such a way as to first allow access of oxygen through the opercular micropyle and to minimize water loss. Subsequently, with increased stress of dehydration, the mantle cavity may remain completely closed and an anaerobic milieu set up. The present results confirm that under these conditions the metabolic rate, either aerobic or anaerobic, is grossly reduced and indicate that this is related to a fall in the ATP, concomitant with a reduction, of a closely similar proportion (about half), in the ATP-ase; there may also be recourse to an alternative metabolic pathway. In C. depressus this fall in the ATP content, associated with a reduction in the resting value of the oxygen uptake, takes place within the first three days after the animals have been taken out of water.

The ATP value for the immersed animals may be considered representative of the steady state with food available. On transference to air food is withheld and the 
animal must either draw on reserves or resort to cellular breakdown. The fall in ATP in air presumably reflects a lowered rate of metabolism which may depend initially on the rate at which substrate can be mobilized from reserves. The accumulation of glucose-6-phosphate within six days indicates that subsequent reactions soon become limiting. On resort to anaerobic metabolism the ATP production - per unit weight of substrate - will be further lowered. The greatly reduced metabolic rate as measured by oxygen uptake, the reserve food utilized, or the lactic acid produced, can be explained in this way (BARNES, Barnes \& Frntayson 1963b). It must be remenbered, however, that initially, intact animals respire normally in sea water and under nitrogen produce large quantities of lactic acid (Barnes, Finlayson \& PiatiGORSKY 1963). It would seem that dehydration plays a further important part. It has already been shown that dehydration whether produced by direct water loss to the air or by maintenance in hypersaline solutions leads to a very marked depression in respiration (BARnes, FinLaYson \& PIATIGORSKY, loc. cit.) and it is probably this reduced demand on metabolism which allows the animals to remain viable for long periods out of water. The following sequence of events may be envisaged: on transference to air access to the latter is at first maintained via the micropyle and aerobic respiration, at the reduced rate under conditions characteristic of inanition, continues; there will be water loss at this stage. Eventually dehydration stress causes complete occlusion of the mantle cavity and a resort to anaerobiosis; this point is nicely adjusted so that the amount of dehydration is adequate to make a reduced metabolic rate acceptable without affecting the viability. Reserves are only slowly used up and the animal can remain alive for long periods. Once a certain proportion of the carbohydrate has been used up both protein and fat are mobilized (BARNEs, BARnes \& FinLAYYSON 1963a, b) and in the case of fat the metabolic water may help to maintain optimal hydration. Ultimately the accumulation of toxic products such as lactic acid or the depletion of reserves and cellular destruction kill the animal.

The biochemical differences between species occupying the upper and lower parts of the intertidal may be one of degree rather than of kind, the vertical separation being effected not by marked biochemical differences in response to the environment but rather by competition and factors related to cyprid settlement which tend to prevent competition. In the case of Balanus balanoides and Chthamalus stellatus, the latter being found above the former when they occur together, BARNEs, Finlayson \& Piatigorsky (1963) have already stressed that the difference between the survival times in dry air at moderate temperatures is not great and that the lower metabolic rate associated with Chthamalus sp. may be a more important factor in allowing a longer survival of $C$. stellatus. This may be equally true of $C$. depressus in relation to $C$. stellatus since it will be shown that the conditions for the settlement of C. depressus are quite specialized (BARNes $8 x$ BARNEs 1964). On continued inanition substrates other than glucose (glycogen) are used when the animals are maintained under water (BARNES, BARNES \& FINLAYSON 1963b) and the behaviour of nonglucosidic substrates and the associated enzyme systems may be important in differentiating high and low level species.

Further interest centres round any inter-specific differences and in the details of the way in which individual enzyme systems adapt to exposure. 


\section{SUMMARY}

1. The effect of exposure to air on the oxygen uptake, lactic acid production, and quantities of certain phosphoryleated intermediates of $C$. depressus has been determined.

2. On transference to air, aerobic conditions with a reduced metabolic rate are first maintained; access of oxygen and water loss are controlled by the opercular micropyle.

3. Dehydration stresses then lead to occlusion of the mantle cavity and subsequent anaerobiosis.

4. Starvation results in a lower metabolic rate, aerobic or anaerobic, and a reduced demand for substrates now mobilized from reserves.

5. The reduced demand is also related to the amount of dehydration and the latter is so adjusted to allow viability over a long period.

6. Eventually toxic products kill the animal.

\section{LITERATURE CITED}

Barnes, H., 1958. The growth rate of Verruca stroemia (O. Müller). J. Mar. biol. Ass. U. K. 37, $427-433$.

- \& Barnes, M., 1959. Studies on the metabolism of cirripedes. The relation between body weight, oxygen uptake, and species habitat. Veröf. Inst. Meeresforsch. Bremerbaven 6, 515-523.

-, - 1964. Répartition et écologie générale des Cirripèdes Chthamalus depressus (Polli) et C. stellalus (Polli) le long des côtes mediterranéenes d' Espagne et de France. Bull. Inst. océanogr. Monaco 62, No. 1299, 19 pp.

- Barnes, M. \& Finlayson, D. M., 1963a. The seasonal changes in body weight, biochemical composition, and oxygen uptake in two common boreo-arctic cirripedes Balanus balanoides \& B. balanus. J. Mar. biol. Ass. U. K. 43, 185-211.

- Barnes, M. \& Finlayson, D. M., 1963b. The metabolism during starvation of Balanus balanoides. J. Mar. biol. Ass. U. K. 43, 213-223.

- Finlayson, D. M. \& Piatigorsky, J., 1963. The effect of desiccation and anaerobic conditions on the behaviour, survival and general metabolism of three common cirripedes. J. anim. Ecol. 32, 233-252.

ENNOR, A. H., 1957. Determination and preparation of $\mathrm{N}$-phosphates of biological origin. In: Methods in Enzymology, edited by Colowrck, S. P. \& Kaplan, N. O., Academic Press Inc. New York, Vol. 3, 850-860.

Hesrop, J. P., Price, G. M. \& Ray, J. W., 1963. Anaerobic metabolism in the housefly, Musca domestica L. Biochem. J. 37, 35-38.

Monterroso, B., 1932. Studi cirripedologici VIII. Esperienze e considerazioni sulla sopra vivenza di Chtbamalus stellatus Ranzi in olio di vaseline. Atti Accad. gioenia Sci. nat. Ser. (5) 19, 1-9.

Morrison, J. F. \& EnNor, J. H., 1960. N-phosphorylated guanidines. In: The Enzymes, 2nd ed., edited by Boyer, P. D., Landy, H. \& Myrbäck, K. Academic Press Inc. New York and London, Vol. 3, 89-109.

RaY, J. W. \& Heslor, J. P., 1963. Phosphorus metabolism of the housefly (Musca domestica L.) during recovery from anoxia. Biochem. J. 87, 39-42.

Umbreit, W. W., Burris, R. H. \& Stauffer, J. F., 1945. Manometric techniques and related methods for the study of tissue metabolism. Burgess Publ. Comp. Minneapolis, Minn., $203 \mathrm{pp}$. 


\section{Discussion following the paper by BARNES \& BARNES}

Crisp: There was one point in the curves of the barnacles under stress which I could not fully appreciate. I noticed there was a large difference in survival between those animals in dry nitrogen and those animals in wet nitrogen. Now in both cases the animals would be unable to respire, and I would have thought it would not have mattered whether they closed their opercula or not. The survival time, I would have thought, depended entirely upon lack of oxygen. Can you explain why there was this difference between those in wet and dry nitrogen?

Barnes: Yes, I think so. The experiments show that the animals can in fact respire anaerobically, and therefore in wet nitrogen when there is no stress of dehydration, they have a longer survival time. Animals in wet nitrogen open up and under the stress of wet nitrogen (anaerobic conditions) then stay open; they behave similarly to a sublittoral species under wet nitrogen and have roughly about the same survival time. It is simply that they can withstand anaerobic conditions for a time; in dry nitrogen there is the additional stress of dehydration added to anaerobic stress.

CRISP: How does survival compare in dry air and dry nitrogen?

Barnes: The survival times are similar in dry nitrogen, but dry air causes the maximum difference between the intertidal and sublittoral species.

WIESER: Do incomplete breakdown products other than lactic acid accumulate in barnacles? Have appropriate checks been made? It is often assumed that the diffusion of oxygen and of water across biological membranes has the same constants. Does this always apply? Are there not cases known in which oxygen diffuses faster than water and could this not - if it is applied to intertidal animals - affect the relationship between uptake of oxygen and loss of water in these animals?

BARNES: Since there was such an enormous production of lactic acid, and since this therefore was clearly the main product of anaerobic metabolism, no search was made for other products which are known to accumulate under these conditions.

Prosser: What changes occur in lipids during the anaerobic period? Could these be a source of some of the metabolic intermediates?

BARNES: This has not been investigated. Under staryation, lipid is utilized. 